\title{
Increased aeolian activity during humidity shifts as recorded in a raised bog in south-west Sweden during the past 1700 years
}

\author{
R. de Jong ${ }^{1}$, K. Schoning ${ }^{2}$, and S. Björck ${ }^{1}$ \\ ${ }^{1}$ Geobiosphere Science Centre, Quaternary Sciences, Lund University, Sweden \\ ${ }^{2}$ Department of Physical Geography and Quaternary Geology, Stockholm University, Sweden
}

Received: 19 February 2007 - Published in Clim. Past Discuss.: 27 February 2007

Revised: 25 June 2007 - Accepted: 5 July 2007 - Published: 13 July 2007

\begin{abstract}
Analyses of testate amoebae and aeolian sediment influx (ASI) were used to reconstruct effective humidity changes and aeolian activity in the coastal zone of southwest Sweden. Cores were taken from an ombrotrophic peat sequence from the Undarsmosse bog. Since both types of analysis were carried out on the same core, a direct comparison between humidity fluctuations in the bog and aeolian activity was possible, potentially providing detailed information on atmospheric circulation changes in this region. Relatively wet bog surface conditions occurred from around 1500 to 1230 and 770 to 380 cal. yrs BP, whereas dry conditions dominated from ca. 1630 to 1530,1160 to 830 and 300 to 50 cal. yrs BP. The transitions between these phases occurred within $60-100$ years and are characterised by a major change in the testate amoebae assemblages. A watertable reconstruction was used to study the hydrological changes at the bog surface in more detail. ASI peak events were reconstructed around 1450, 1150, 850 and after 370 cal. yrs BP. Most interestingly, these aeolian activity peaks started during the recorded hydrological transitions, regardless of the direction of these shifts. Our results therefore suggest that humidity shifts in this region were associated with temporary intensifications of atmospheric circulation during the past 1700 years. Several ASI peaks apparently coincide with reduced solar activity, possibly suggesting a solar related cause for some of the observed events.
\end{abstract}

\section{Introduction}

Storm frequency and intensity in the coastal regions of southern Scandinavia are mainly controlled by the position of the westerly storm tracks in the North Atlantic and the frequency of atmospheric blocking. Since cyclones exert an important control on summer and winter temperatures (Jönsson and

Correspondence to: R. de Jong

(rixt.de_Jong@geol.lu.se)
Fortuniak, 1995) and precipitation, the proximity of cyclone tracks and the intensity and frequency of generated storms form a major control on the climate in south-west Sweden. To explain climatic changes occurring in this region therefore, information is needed on parameters that are related to climate, such as precipitation and evaporation and storm frequency and intensity. Knowledge on these climatic parameters could lead to increased understanding of changes in atmospheric circulation in the North Atlantic region.

Study sites along the south-west coast of Sweden are ideally placed to register changes in atmospheric circulation patterns. Changes in effective humidity in north-west Europe have been reconstructed from peat bogs (e.g. Van Geel et al., 1996; Hughes, 2000; Mauquoy et al., 2002a; Barber et al., 2003; Borgmark, 2005; Charman et al., 2006). Ombrotrophic peat bogs in particular appear to be good archives for humidity changes, since their water supply is entirely dependent on precipitation and therefore reflect changes in this parameter (Barber, 2003). Furthermore, lake studies in south-central Sweden using isotope analysis (Hammarlund et al., 2003; Seppä et al., 2005) or stratigraphically based lake level reconstructions (Digerfeldt, 1988; Almquist-Jacobson, 1995) also provide estimates of effective humidity through time.

Storm frequency and intensity in Scandinavia have been reconstructed indirectly by studying the development of dune areas, in particular the timing of the onset of dune formation. However, other factors such as human impact and sea level variations have also been mentioned as causes for dune formation (Clemmensen et al., 2001a, b; Clarke and Rendell, 2006). Dune development studies have been carried out along the western European coastline (e.g. Clemmensen et al, 2001a, b; Wilson et al., 2001, 2004; Clarke et al., 2002; Clarke and Rendell, 2006) and show broad agreement on the timing of dune development phases. A different approach to reconstruct aeolian activity has been shown by Björck and Clemmensen (2004), who studied two raised bog sites in south-west Sweden. They reconstructed the sand content of

Published by Copernicus Publications on behalf of the European Geosciences Union. 


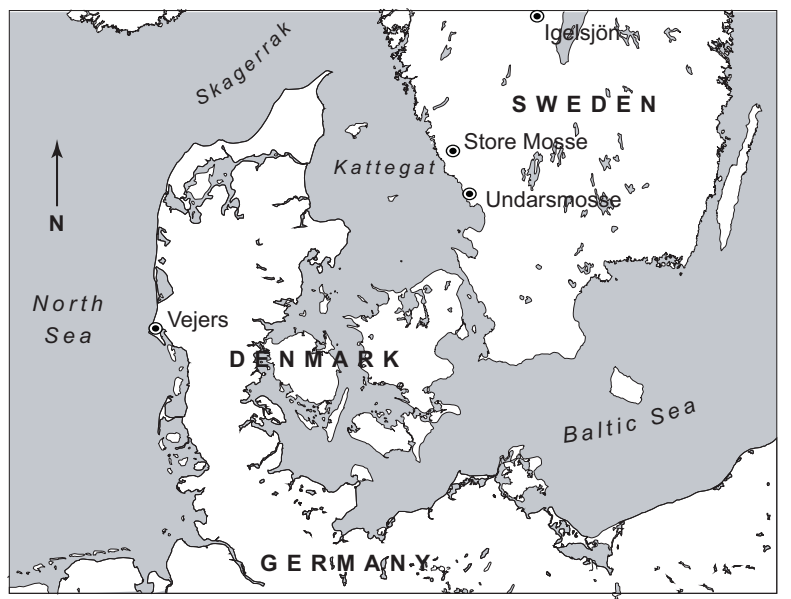

Fig. 1. map showing the location of the Undarsmosse and Store Mosse bogs on the south-west coast of Sweden. The locations of two other sites mentioned in the text (Vejers dunefield, lake Igelsjön) are also shown.

peat samples and interpreted these as a proxy for aeolian sediment influx (ASI), since minerogenic material could only have been transported to the centre of these bogs by wind. However, apart from climatic factors, human land use may also exert a control on ASI by affecting sediment availability (De Jong et al., 2006).

For the area of north-west Europe there are thus a number of proxy records available on humidity and storminess changes. However, most records available from south Scandinavia focus on long term climatic trends. Not much is known about the shorter term fluctuations that occurred during more recent time. Furthermore, a comparison between the different datasets from dune areas, lakes and peat bogs is difficult due to inherent differences in dating methods and uncertainties in chronology. Therefore it is not easy to deduce the relation between the reconstructed climatic parameters directly.

Here we present a study in which bog surface humidity fluctuations and aeolian activity have been reconstructed from the same core from a raised bog site, the Undarsmosse bog, in south-west Sweden (Fig. 1). Testate amoebae analysis was used to reconstruct relative changes of the bog surface wetness status, which reflects the hydrological balance of the bog. ASI analysis was used to reconstruct aeolian sediment influx, a proxy for storm frequency and/or intensity. To study the regional pattern of aeolian activity, the ASI record from the Store Mosse bog, also situated in the coastal zone of Halland, is presented here as well (Fig. 1). We show that during the past 1700 years hydrological shifts have been accompanied by increased aeolian activity in this region. We discuss the possible causes for this relation and the implications for the characteristics of atmospheric circulation during these shifts.

\section{Site description}

\subsection{Undarsmosse bog}

The Undarsmosse bog is situated on the coastal plain of Halland at $1.5 \mathrm{~km}$ from the present coastline (Fig. 1). The beach areas and the coastal plain are characterised by beach ridges and extensive dune areas, wave reworked tills, moraine ridges and bedrock outcrops (Påsse, 1987, 1988). The study site is an ombrotrophic bog situated at $20 \mathrm{~m}$ above sea level. The areal extent of peat deposits is ca. 120 ha. The modern bog surface is, however, approximately only half that size due to extensive peat cutting which started around AD 1925, when a deep drainage channel was dug along the eastern margins of the bog. However, historical records indicate that peat cutting had commenced already before that time (Adern, 1973). Cores were taken in the untouched part of the bog in the northern central part of the basin. Vegetation here is dominated by Sphagnum in the bottom layer and Calluna vulgaris and other Ericaceae in the field layer.

\subsection{Store Mosse bog}

The Store Mosse bog (Fig. 1) is situated on the eastern limit of the coastal plain at the transition to the higher upland area in the east. The coastal plain is ca. $12 \mathrm{~km}$ wide here and is characterised by sandy and silty wave-reworked glacial deposits (Påsse, 1989). Active sand dune areas are found at a distance of $6 \mathrm{~km}$ to the west and south-west. The total areal extent of fen and peat deposits is ca. 240 ha. The peat bog surface has been subjected to severe peat cutting, so that only narrow ridges of the original peat surface remain. Cores were taken from such a ridge in the northern central part of the peat bog, where the disturbance of the sediment was thought to be relatively small. However, due to the intense drainage and peat cutting, conditions at the coring site are dry. The vegetation is dense and dominated by Calluna vulgaris and other heath types in the field layer. Tall birch and pine trees grow in the direct vicinity of the coring site. A detailed description of the study sites is provided in De Jong et al. (2006) and De Jong (2007)

\subsection{Climatological setting}

The province of Halland is strongly affected by westerlies, resulting in a mild oceanic climate with cool summers $\left(16^{\circ} \mathrm{C}\right.$ July average temperature) and relatively mild winters $\left(-4^{\circ} \mathrm{C}\right.$ January average temperature). Annual precipitation near the Undarsmosse bog is around $800-900 \mathrm{~mm} \mathrm{yr}^{-1}$, whereas precipitation near the Store Mosse bog is higher, between 1000 and $1200 \mathrm{~mm} \mathrm{yr}^{-1}$. The mean number of days with snow cover varies between 75 and 100 days (Raab and Vedin, 1995). The weather is, however, extremely variable being controlled by the frequency, intensity and position of the passing cyclones. Analysis of geostrophic wind speeds in south Sweden from 1881 to 1997 shows that winds from 
Table 1. The testate amoebae are grouped into three different wetness categories based on their wetness preferences on peat bogs.

\begin{tabular}{lll}
\hline Wet indicators & Indifferent & Dry indicators \\
\hline Amphitrema flavum & Assulina seminulum & Assulina muscorum \\
Amphitrema wrightianum & Centropyxis cassis type & Bullinilaria indica \\
Arcella discoides type & Cyclopyxis arcelloides & Corythion-Trinema type \\
Centropyxis aculeata type & Difflugia pristis type & Difflugia pulex \\
Difflugia leidyi & Heleopera rosea & Euglypha rotunda type \\
Euglypha compressa & Nebela tincta & Nebela militaris \\
Euglypha strigosa & Sphenoderia lenta & Heleopera petricola \\
Hyalosphenia elegans & & Heleopera sphagni \\
Hyalosphenia papilio & & Trigonopyxis arcula type \\
\hline
\end{tabular}

a westerly direction dominated the wind spectrum entirely and the relative storm frequency was highest between October and March (Alexandersson et al., 1998; 2000; Nilsson et al., 2004). These westerly storm winds are caused by cyclones passing north of Halland towards the east (Jönsson, 1994). Easterly winds of storm force occasionally occur when cyclones pass south of Halland, and are often associated with a high pressure field situated over northern Scandinavia. However, during the past century easterly storm winds (geostrophic wind speed $>20 \mathrm{~m} \mathrm{~s}^{-1}$ ) have been rare (Nilsson et al., 2004).

\section{Methods and materials}

Corings were carried out in the central part of the bogs using a Russian peat sampler $(7.5 \mathrm{~cm} \varnothing)$. The cores were taken from two parallel holes with sufficient overlapping to ensure full stratigraphic recovery. The cores were described in detail in the field and stored in a deep freezer. The cores from the Undarsmosse bog were cut into $2 \mathrm{~cm}$ segments in the upper meter of the core and $1 \mathrm{~cm}$ segments in the lower part. The total depth of organic deposits was $339 \mathrm{~cm}$. The cores from the Store Mosse bog were cut in $1 \mathrm{~cm}$ segments throughout the core. At this site the total thickness of the organic deposits was $350 \mathrm{~cm}$. Details on sediment characteristics for peat representing the last ca. 2000 years are shown in Fig. 2 for both localities.

Each segment was sampled for ash-free organic bulk density, ignition residue and the mineral grain content. Pollen analysis was carried out on samples from both cores following standard methods as described by Berglund and Ralska-Jasiewiczowa (1986) and Moore et al. (1991), with an overnight cold HF treatment to ensure that quartz particles were dissolved. Testate amoebae analysis was carried out on samples from the Undarsmosse bog only, at 29 levels in the upper $160 \mathrm{~cm}$ of the core. ASI was determined at all levels for both study areas.

\subsection{Testate Amoebae analysis}

The testate amoebae sample preparation follows Charman et al. (2000) and Lycopodium spores were added to the samples. At least 150 specimens from the $15 \mu \mathrm{m}-300 \mu \mathrm{m}$ sieve residues were identified in each sample following the taxonomy of Grospietsch (1958) and Charman et al. (2000). The testate amoebae were divided in three hydrological groups: dry indicators, wet indicators and indifferent, based on their ecological wetness preferences (Table 1). This division was applied in order to distinguish major changes in the wetness status of the bog surface. The wetness classification is based on ecological information from Bobrov et al. (1999), Charman et al. (2000) and Charman et al. (2007). Variations in the watertable were reconstructed using the transfer function from Charman et al. (2007), which is based on the relationship between the depth below the peat surface and the depth of the water table in modern testate amoebae assemblages from European bogs. The water table was calculated using tolerance downweighted weighted averaging (WA-Tol) and errors were estimated with 1000 bootstrap cycles.

\subsection{ASI analysis}

Ignition residues from all samples were rinsed in $\mathrm{HCl} 10 \%$ and analysed under a 50x zoom stereomicroscope. All quartz particles $>125 \mu \mathrm{m}$ were counted. In the Store Mosse samples the fraction from $80-125 \mu \mathrm{m}$ was also counted since fewer grains were found in these samples. However, in the comparison between the ASI records we only used the fraction $>125 \mu \mathrm{m}$. The maximum grain-size was measured at all levels. Mineral grain influx values were calculated using the sample resolution provided by the age-depth models (Fig. 2) and volume measurements from each sample. ASI is expressed as the number of grains $\mathrm{cm}^{-2} \mathrm{yr}^{-1}$. A detailed method description is provided in De Jong et al. (2006). 
Table 2. Radiocarbon dates from the Undarsmosse and Store Mosse bogs, calibrated ages and error margins. The radiocarbon dates were calibrated with the IntCal04 calibration curve (Reimer et al., 2004).

\begin{tabular}{ccccc}
\hline & Depth $(\mathrm{cm})$ & ${ }^{14}$ C age & Cal. age BP $(+/-2 \sigma)$ & Lab. No. \\
\hline Undarsmosse bog & $20-22$ & $175+/-50$ & $170+/-160$ & LuS-5839 \\
& $30-31$ & $490+/-35$ & $525+/-35$ & Poz-3593 \\
& $66-68$ & $1055+/-50$ & $990+/-90$ & LuS-5840 \\
& $100-101$ & $1250+/-40$ & $1175+/-105$ & Poz-3594 \\
& $150-151$ & $1605+/-60$ & $1490+/-140$ & LuS-5841 \\
Store Mosse bog & $200-201$ & $2150+/-40$ & $2265+/-45$ or 2105+/-105 & Poz-3595 \\
& $4-5^{*}$ & $990+/-50$ & $882+/-101$ & LuS 6409 \\
& $26-27^{*}$ & $985+/-40$ & $878+/-83$ & LuS 6410 \\
& $35-36$ & $140+/-40$ & $105+/-50$ or 225+/-60 & LuS 6619 \\
& $45-46$ & $470+/-40$ & $507+/-46$ & LuS 6449 \\
& $70-71$ & $850+/-40$ & $743+/-60$ & LuS 6411 \\
& $105-106$ & $1145+/-40$ & $1070+/-100$ & LuS 6412 \\
& $142-143$ & $1540+/-50$ & $1435+/-100$ & LuS 6413 \\
& $181-182$ & $1905+/-40$ & $1830+/-100$ & LuS 6414 \\
& $200-201$ & $2095+/-50$ & $2045+/-115$ & LuS 6620 \\
\hline
\end{tabular}

* Dates at these levels were considered to be too old and were disregarded in the age-depth model.

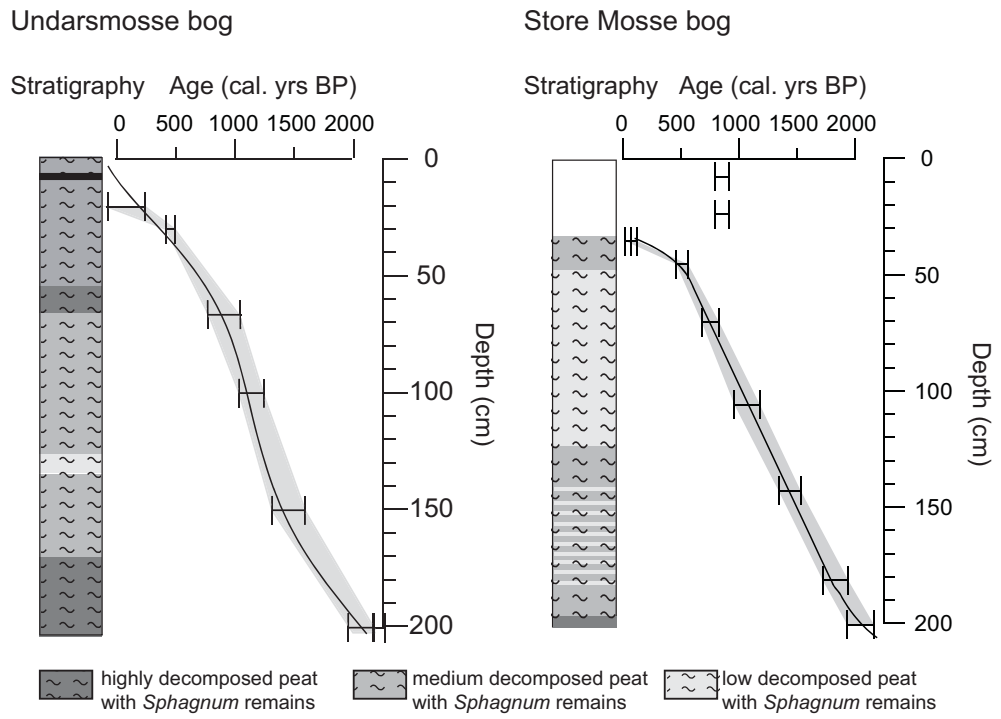

Fig. 2. Stratigraphy and age models for the Undarsmosse and Store Mosse bog. The upper $30 \mathrm{~cm}$ in the Store Mosse bog was omitted from the stratigraphy since this layer is though to have been cut from a deeper adjacent peat section, and placed on the surface to dry. This is indicated by the erroneously old ages, as wel as in the pollen assemblage, organic bulk density values and ASI record.

\subsection{Pollen analysis}

At each analysed level a minimum of 500 pollen grains were counted. In this study, the total percentage of pollen types indicating crop cultivation (Secale, Cerealea) and grassland areas (Poaceae, Taraxacum, Plantago lanceolata, Potentilla, Rumex acetosa/acetosella) are shown separately, since they reflect different aspects of land use. Grazing on heath lands is not taken into account here, although this certainly occurred in the area. However, due to the abundant occurrence of Cal- luna in the bog vegetation, these variations are not only indicative of land use changes. A detailed interpretation and presentation of the complete pollen records can be found in De Jong et al. (2006) and De Jong (2007).

\subsection{Chronology}

The age-depth model for the Undarsmosse bog is discussed in De Jong et al. (2006), and the part covering the last ca. 2000 years is shown in Fig. 2. Dating of the upper 


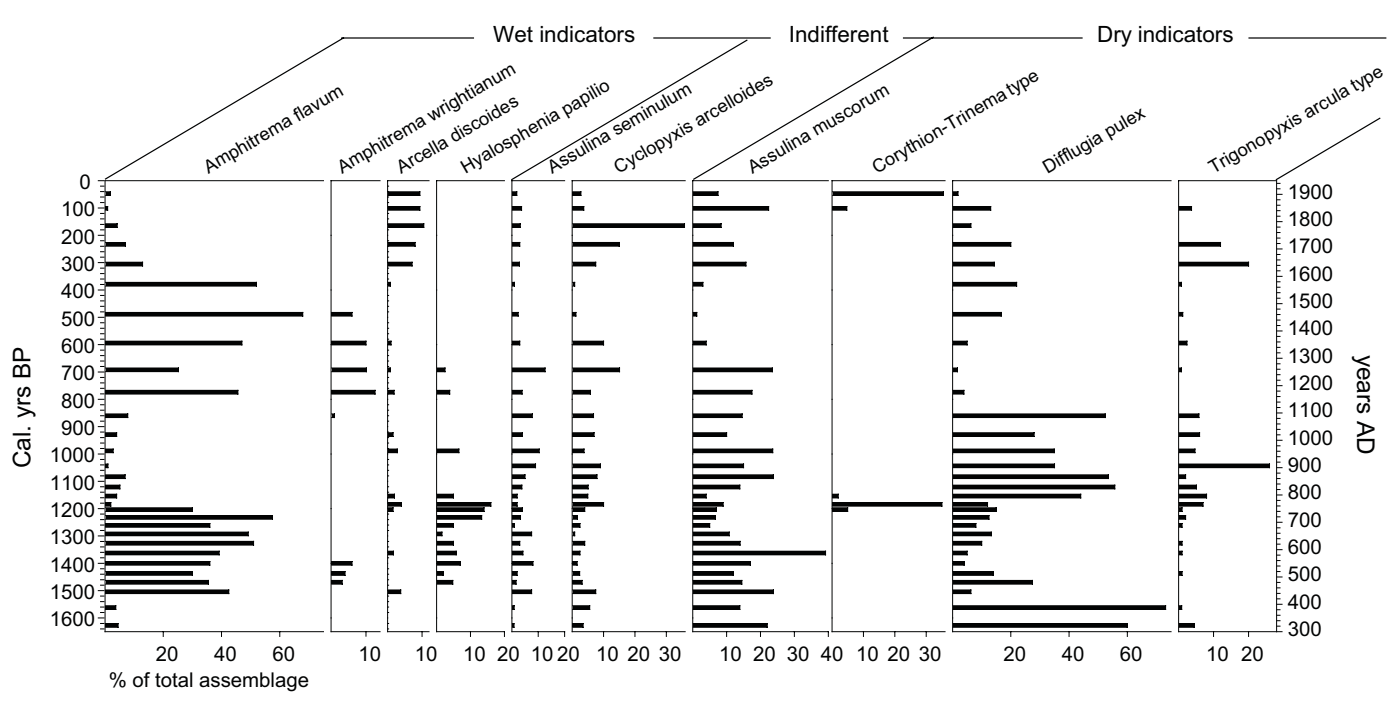

Fig. 3. The most common testate amoebae at Undarsmosse shown as the percentage of total testate amoebae plotted on common timescale (right y-axis) and cal. yrs BP (left y-axis). The testate amoebae are grouped according to their ecological wetness preferences.

$160 \mathrm{~cm}$ of the core is based on five radiocarbon dates on ombrotrophic peat (Table 2). The model is a combination of a seventh and tenth degree polynomial fit.

For the Store Mosse record nine dates on ombrotrophic peat were available for the past ca. 2000 years (Fig. 2 and Table 2). However, the upper two dates provided ages that were considered too old and these are not included in the age model. We believe that these dates may be too old because the peat from which the samples were taken was cut in the adjacent cutting trench and subsequently placed on the surface of the ridge (coring location) to dry. Pollen analysis has shown that the upper ca. $30 \mathrm{~cm}$ of the core, where these samples were taken, has a pollen spectrum that is comparable to the spectrum at $80-90 \mathrm{~cm}$ depth. The level of the "original" bog surface was set at $32 \mathrm{~cm}$ depth, based on changes in ash-free organic bulk density, ASI and pollen analysis (not shown). The age of this level was set at 20 cal. yrs BP, the time when peat cutting intensified in this region (De Jong, 2007). The true age of this level is not known though.

The age model for the Store Mosse bog is based on a linear function, connected to a ninth degree polynomial function between 50 and $32 \mathrm{~cm}$ depth. All radiocarbon dates were calibrated using the IntCal04 calibration curve (Reimer et al., 2004) as implemented in the OxCal 3.10 program Bronk Ramsey, 1995; Bronk Ramsey, 2001). The error margin envelopes in Fig. 2 are based on linear interpolations of the error bars for the $95.4 \%$ confidence level. These error margins should be considered when events reconstructed at different sites are compared. Ages mentioned in the text refer to calendar years before 1950 (cal. yrs BP), unless stated otherwise.

\section{Results}

\subsection{Effective humidity}

The reconstructed effective humidity changes (Fig. 3) are indicative of the hydrological balance of the bog and its wetness status. Three periods with mainly dry conditions, from ca. 1630 to 1530,1160 to 830 and 300 to $50 \mathrm{cal}$. yrs BP, are recognised in the investigated record. During these periods the dominating testate amoebae are Difflugia pulex, Assulina muscorum and Trigonopyxis arcula type (Fig. 3). Two periods with mainly wetter conditions in between the dry phases are also recognised: from ca. 1500 to 1230 and 770 to 380 cal. yrs BP. During the wet phases the testate amoebae assemblages are strongly dominated by Amphitrema flavum with Amphitrema wrightianum and Hyalosphenia papilio as most common associated species (Fig. 3). The uppermost sample (50 cal. yrs BP) is not reliable due to modern drainage of the bog. Testate amoebae concentration and influx values were also calculated, but these did not provide additional information and are not shown here.

In Fig. 5 the changes in testate amoebae assemblages have been summarized in two curves reflecting the effective humidity changes. These show the alternating dominance of wet and dry indicator species. The curves are characterised by periods of 300-400 years of relatively dry/wet conditions, followed by rapid (60-100 years) transitional phases (shaded areas in Fig. 5). In Fig. 5a the watertable reconstruction is also shown, revealing a similar general pattern of alternating wet and dry conditions. However, whereas the testate amoebae assemblages can be used to identify major hydrological shifts, the watertable reconstruction provides more detailed information on the character of the shifts and on short-term variability. 


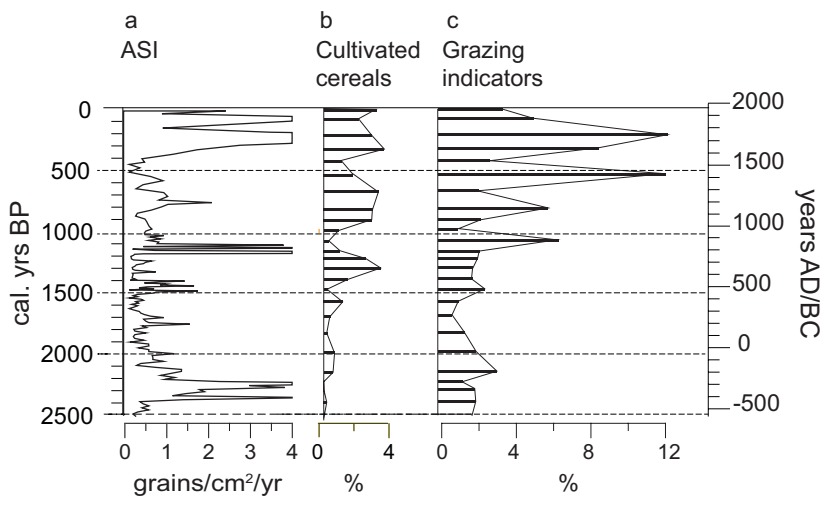

Fig. 4. Comparison between aeolian sediment influx data (ASI) and pollen types indicating land use. Shown are the total pollen percentage for pollen types indicating (b) crop cultivation (Secale, Cerealea) and (c) grassland areas (Poaceae, Taraxacum, Plantago lanceolata, Potentilla, Rumex acetosa/acetosella).

The effective humidity reconstructions from this study have also been compared to records from Lake Igelsjön (Figs. 1, 5c), south central Sweden (Hammarlund et al., 2003; Seppä et al., 2005). Here isotopic variations of $\delta^{18} \mathrm{O}_{\text {sediment }}$ were interpreted as a proxy for the ratio between precipitation and evaporation from the lake basin (Hammarlund et al., 2003). This reconstruction provides a proxy that is comparable to the testate amoebae wetness indicators from this study. Figure 5 shows that the variations observed at Undarsmosse bog are reflected at the Igelsjön site, although the comparison is complicated by the low resolution in the lake record. Nevertheless, the similarities between the records may indicate that the humidity fluctuations are of a regional character. The timing of transitions to wet periods (1500 and 770 cal. yrs BP) recorded here are also coherent with "wet shifts" recorded in many European bog sites (e.g. Hughes et al., 2000; Barber et al., 2003 and references therein), as well as with the classic recurrence surfaces recognised by Granlund (1932) in south Swedish bogs.

\subsection{Aeolian activity}

The results from the ASI analysis from the Undarsmosse bog are shown in Figs. 4 and 5. The ASI record is tentatively interpreted as a proxy for winter conditions (Björck and Clemmensen, 2004). When bogs are frozen and snow covered, sand grains can be transported more easily over the otherwise irregular and vegetated bog surfaces. Flat and open areas such as beaches and elevated areas such as dunes, on the other hand, would lose most of their snow cover during strong winds, thereby enabling wind erosion of the mineral particles underneath. Snow drifting, or niveo-aeolian transport, would greatly facilitate the transport of large sand grains over the bog surface. Since the grainsizes under consideration here $(>125 \mu \mathrm{m})$ are generally transported as bed- load (Tsoar and Pye, 1987), thus saltating or creeping, it is difficult to explain the occurrence of these grains in the central part of large bogs otherwise. So, although exceptional wind speeds may transport medium size grains over some distance during all seasons, the majority of the sand grains have most likely been transported under niveo-aeolian conditions (cf Dijkmans, 1990; Lewkowicz, 1998).

In Fig. 5 the results are shown for ASI influx at Undarsmosse bog, including all sand grains $>125 \mu \mathrm{m}$ for the last 1700 years. For comparison the ASI data from the Store Mosse bog (Figs. 1, 5d) and the timing of onset of dune development at Vejers dunefield, west Denmark (Figs. 1, 5e), are also shown (Clemmensen et al., 2001a, 2006). The timing of ASI peaks at the two bog sites is remarkably similar despite the different settings of each site and the distance between them of ca. $60 \mathrm{~km}$. Small differences in timing of the events are well within the range of dating errors. Peak events are recorded from around 1500-1400, 1180-1100, 850-700 and after 370 cal. yrs BP. The largest peaks occur around 1150 and 250 cal. yrs BP. However, since these peaks take place at a transition to dry conditions (Sect. 5.2) it is not possible to obtain certainty on the precise duration or the amplitude of these specific ASI peaks. It is known that the increase in peat humification at the transitions to generally dry conditions compacts the peat and also leads to a secondary decomposition (Tipping, 1995; Borgmark and Schoning, 2006). The age-depth model does not reflect such short-term fluctuations in peat accumulation, and the duration as well as the amplitude of these peaks may thus be overestimated. In addition, it is important to realise that peak ASI events may be related to a limited number of severe storms.

A comparison to the initiation of dune activity at Vejers dunefield shows many apparently simultaneous events (Fig. 5). Together the curves from Halland and the record from Vejers dunefield suggest that the reconstructed peak periods reflect increased aeolian sediment transport on a regional scale. This could be related to changing land use, affecting sediment availability, or climatic factors controlling winter storm frequency and/or intensity. Unfortunately it is not possible to deduce the dominant wind direction directly during ASI peak events. The mineral composition of the sand is homogenous (quartz) and available in all wind directions. However, the simultaneous onset of dune development in west Denmark during three out of four ASI peak events (Fig. 5) suggests that these ASI peaks are related to westerly wind directions, although dune reactivation phases may be more related to spring and summer storms (Clemmensen and Murray, 2006). However, before a hypothesis on the occurrence and timing of the ASI peaks and humidity shifts can be formulated, the role of human land use has to be looked at since this potentially exerts a major control on sediment availability (Li et al., 2004). 


\subsection{Human land use and aeolian sediment transport}

Pollen analysis at the Undarsmosse site has shown that landscape opening increased strongly after $2800 \mathrm{cal}$. yrs BP (de Jong et al., 2006). As a result, both ASI peak amplitudes and the level of "background noise" increased. This suggests that after 2800 cal. yrs. BP sediment availability was not a limiting factor for aeolian transport to take place. Detailed comparisons between the ASI curves from this study and the Store Mosse bog and their respective pollen diagrams (de Jong et al., 2006; De Jong, 2007) do not show a clear link to human land use at the time of ASI peak events; on the contrary, ASI peaks occur when land use is low (de Jong, 2007). This can also be seen in Fig. 4, where ASI and pollen percentages indicating cereal cultivation and grassland areas can be compared directly in the Undarsmosse record. In general, ASI peaks during the past 2500 years occurred when pollen indicating crop cultivation are few or absent (De Jong, 2007; Figs. 4a-b). This can clearly be seen at the Undarsmosse site around 2300, 1500 and $1150 \mathrm{cal}$. yrs BP.

Grassland indicators are more difficult to interpret (see De Jong, 2007), but these do not show a clear relation to ASI peak events either. A detailed comparison between grassland indicators and ASI (Figs. 4a, c) shows, that some ASI peaks are immediately followed by increases in grassland (e.g. around 2300 and 1150 cal. yrs BP), indicating that increased grazing could not have caused these increases of sand influx. Other ASI peaks (around 750 and $300 \mathrm{cal}$. yrs BP) do coincide with high grassland values. However, the very strong increases of grassland pollen around 1050 and 500 cal. yrs BP can not be linked to increases in the ASI values, as would be expected if a causal link existed. Therefore, increases in crop cultivation or grazing areas can not be causally linked to the timing of ASI peaks. A climatic forcing of the ASI peak events is thus inferred. The strong increase of ploughed and grazed land areas, however, has undoubtedly contributed to the high amplitude and long duration of the peaks recorded here, in particular after ca. 350 cal. yrs BP.

\section{Discussion}

In Fig. 5a the ASI data and effective humidity reconstructions from the Undarsmosse bog are compared. Since samples were taken from the same cores a direct comparison between the timing of events is possible. The results show that major shifts in the testate amoebae assemblages were accompanied by increased aeolian activity regardless of the direction of the shift. A possible exception is the ASI maximum recorded after ca. 350 cal. yrs BP. Although the increase of ASI starts at the transition from wet to dry conditions, the largest part of the peak falls within the period after the transition. A comparison between the watertable reconstructions and ASI fluctuations shows, however, that although the ASI shifts occur during the general shift of testate amoebae assemblages, several ASI peaks tend to coincide with a temporary increase of the water table. This can be seen around 1500-1400, 11501100 and around 750 cal. yrs BP, but not during the more recent ASI peaks. Although this seems to indicate a short increase of bog surface wetness during these three ASI peaks, the error margins of the watertable reconstruction have to be kept in mind and a more detailed interpretation of this potential link is not possible.

\subsection{Humidity shifts and atmospheric circulation changes}

The hydrological balance of the bog and its wetness status mainly depend on evapotranspiration and the amount of precipitation reaching the bog surface. The climate parameters governing the bog surface wetness seem to be different in different geographical regions and climatic settings (Charman et al., 2004; Schoning et al., 2005). In this coastal setting it is likely that the water balance is controlled mainly by precipitation, not summer evaporation. Here, wet conditions are interpreted as a result of wet and cool summers and/or wet winters. Dry conditions indicate a summer water deficit for evaporation, which is not counteracted by precipitation in the other seasons. Cool and wet conditions in this region are related to oceanic conditions with the frequent passage of cyclones, thus a dominance of oceanic westerly air masses. Such a situation indicates that circulation is predominantly zonal (Jönsson, 1994). Winters may have been mild and wet and possibly dominated by an $\mathrm{NAO}^{+}$type of circulation (Hurrell, 1995). Dry conditions in south-west Scandinavia dominate when cyclone frequency is low. Such a situation is associated with a general dominance of continental conditions and high air pressures over the study area. This may imply that meridional air flow intensified, causing a more frequent occurrence of atmospheric blocking situations.

The effective humidity data suggest that throughout the past 1700 years the climatic conditions fluctuated between two dominant types of circulation. Zonal circulation and oceanic conditions dominated between ca. 1500 and 1230 cal. yrs BP and from 770-380 cal. yrs BP. The relatively dry conditions occurring before 1530 and from ca. 1160-830 cal. yrs BP are associated with dry conditions and more frequent atmospheric blocking, which may reflect low annual precipitation and warmer summer conditions.

The periods associated with predominantly dry or wet conditions reconstructed here can be compared to the timing and characteristics of known -and debated- periods such as the Little Ice Age (LIA) and the Mediaeval Warm Period (MWP) (e.g. Grove, 2001; Maasch et al., 2005; Matthews and Briffa, 2005). In Fig. 5 the local timing and duration of these periods is derived from the changes in the testate amoebae assemblages as reconstructed in this study. The dry period around 1160-830 cal. yrs BP (AD 790-1120) may be correlated to the so-called Mediaeval Warm Period (AD 800-1200; Maasch et al., 2005). 


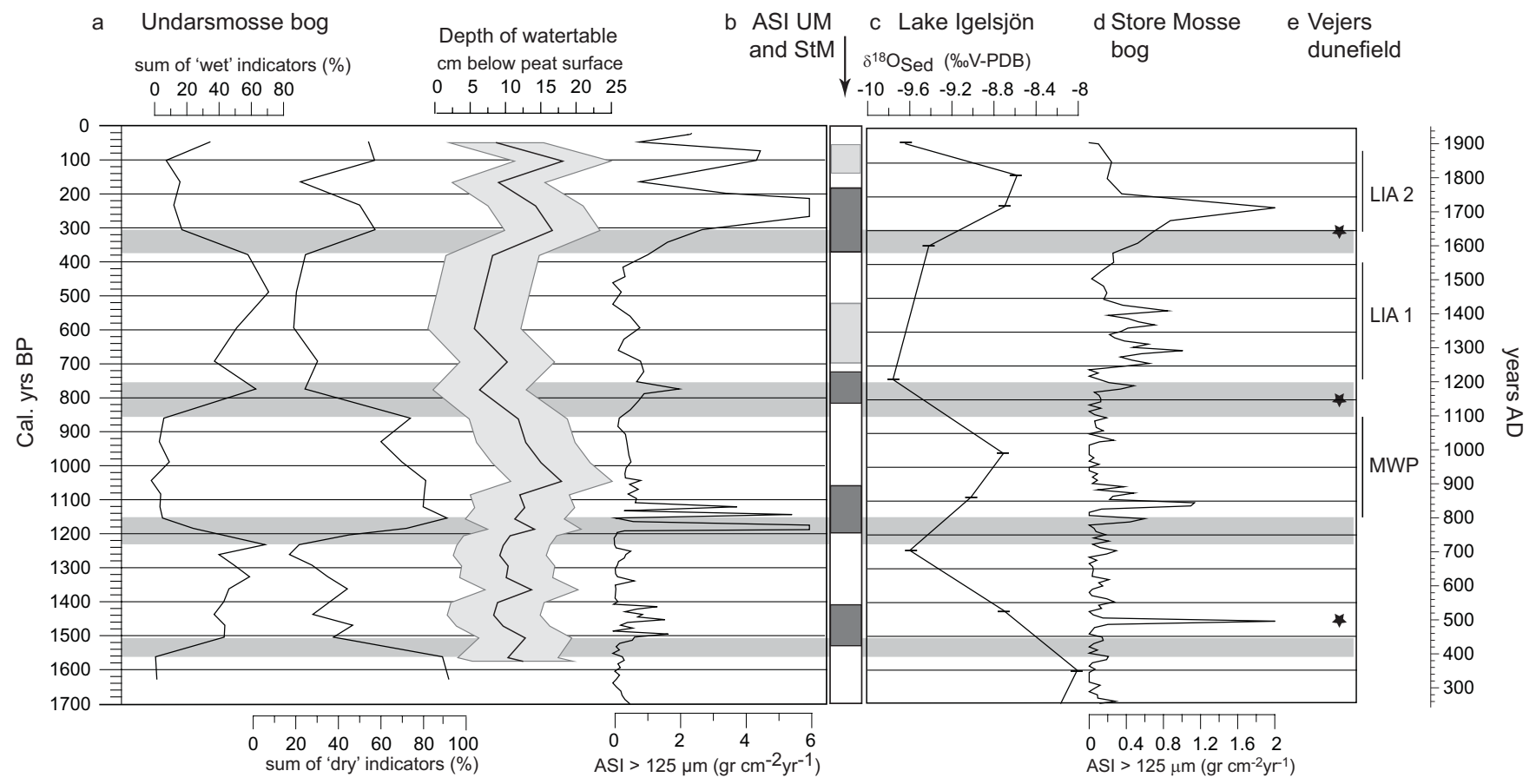

Fig. 5. (a) data from Undarsmosse bog, showing humidity fluctuations as reconstructed by testate amoebae analysis, with an alternating dominance of wet and dry indicators. Curves are based on the taxa presented in Fig. 3 and Table 1. Grey shading indicates transitional phases between relatively stable hydrological conditions as reconstructed by testate amoebae assemblage shifts. The watertable variations (in $\mathrm{cm}$ below the peat surface) are shown with the error margins (after Charman et al., 2007). Also shown are ASI variations from the Undarmosse core for grainsizes $>125 \mu \mathrm{m}$. (b) Summary of ASI data from Undarsmosse and Store mosse bogs (curve d). Dark grey boxes indicate the timing and duration of increased aeolian activity at both sites. Light grey boxes represent increased aeolian activity recorded at one of the sites. (c) Effective humidity changes as recorded by Hammarlund et al. (2003) and Seppä et al. (2005). This proxy is comparable to the wetness indicators at this study site (Fig. 3a) and shows a similar pattern. Datapoints are indicated with horizontal bars. (d) ASI results from Store Mosse bog. Comparison to the ASI record from Undarsmosse bog shows that the two records are highly similar. (e) Stars indicate the onset of dune formation at Vejers dunefield (Fig. 1), interpreted as a proxy for westerly storm activity and sand erodibility (Clemmensen et al., 2001; Clemmensen and Murray, 2006). The inferred local timing of the twofold Little Ice Age (LIA) and the Mediaeval Warm Period (MWP), based on the humidity shift recorded in this study, are also shown.

The LIA as shown in Fig. 4 is divided in two main phases; a wet first phase from around 770 until 300 cal. yrs BP (AD 1180-1650) and a dry phase during the most severe part of the LIA from ca. 300-50 cal. yrs BP (AD 1650-1900). This is in broad agreement with e.g. Grove (2001), who showed an early onset of the LIA in Scandinavia and the Swiss Alps near the end of the thirteenth century and Maasch et al. (2005), who also found a two-fold division of the LIA. It is known, however, that the timing, duration and intensity of these climatic events differ widely (Jones and Briffa, 2001; Ogilvie and Jonsson, 2001; Bradley et al., 2002).

The most recent dry phase (300 to 50 cal. yrs BP) is represented by a fluctuating but generally dry bog surface, suggesting predominantly continental conditions with low precipitation. Many studies indicate severe conditions with very cold winters but also decreased summer temperatures during parts of this time period (e.g. Lamb, 1982; Briffa, 1992; Bradley et al., 2002; Mauquoy et al., 2002). The cooling of both summer and winter temperatures during this time period has been associated with processes related to reduced solar activity (e.g. Shindell et al., 2001; Bond et al., 2001; Mauquoy et al., 2002b), increased volcanic activity (e.g. Briffa et al., 1998; Crowley, 2000) and even reduced greenhouse gas emissions due to a steep population decrease in the Americas (Ruddiman, 2006).

The interpretation of effective humidity in terms of long term changes in dominant atmospheric flow type does not imply that flow patterns were stable during these climatic regimes. Short term atmospheric and climatic changes such as those reconstructed by e.g. tree ring reconstructions from northern Fennoscandia (Briffa et al., 1992; Grudd et al, 2002) and modelling studies (Moberg et al., 2005; Gouirand et al., 2006) certainly took place, but due to the sample resolution in this study short lasting changes are not recorded in our data much. Our data indicate, however, that long term changes in the dominant circulation mode occurred and that the changes from predominantly wet to dry and dry to wet conditions took place within 100 years. 
5.2 Aeolian activity peaks and atmospheric circulation changes

Humidity variations recorded at the Undarsmosse site thus appear to be related to long term fluctuations of the dominant atmospheric circulation mode. Most interestingly, ASI peak events start during these shifts and continue for some decades into the next climatic regime (Fig. 5), indicating that the conditions during these transitions were exceptional in several ways; storms were more frequent, stronger and/or more erosive than storms associated with the more stable dry or wet conditions in between. This relation was also noted in historical records, which show an increase in severe sea floods along the coastlines of the North Sea and the English Channel after AD 1000, at the transition to a cooler and wetter climate which began to affect Europe soon after, during the 13th and 14th century (Lamb, 1982).

Because the majority of ASI peaks occurs during or immediately after a climatic shift, a causal relation between the two types of records is suggested. A tentative hypothesis for the occurrence of ASI peaks during climatic shifts is that the intensification of atmospheric circulation could be a result of the regime shift itself. A large scale alteration of the general atmospheric set-up may cause increased atmospheric mixing, since air pressure contrasts could be large during a period of atmospheric reorganization. This hypothesis implies that climatic shifts could lead to temporarily increased aeolian activity in our study area regardless of the direction of the change. If correct, this hypothesis may also imply that the increased stormy conditions in the North Sea region between AD 1960 - 1990 could be directly related to the rapid climatic warming that is observed during the last few decades (Furevik and Nilsen, 2005). However, the relatively long duration of the ASI peaks (c. 30 to 100 yrs) could be used as an argument against this hypothesis, since atmospheric circulation changes are known to be among the most rapid processes in the climate system. In a detailed GISP2 ice core record of the last 1000 years a conspicuous peak of $\mathrm{Na}^{+}$concentration is recorded between AD 1921 and 1925 (Dawson et al., 2003), reflecting strongly increased storm activity at a climatic transition from very cold conditions to the post AD 1927 amelioration at the GISP2 site. The authors suggest that this "termination" may represent the end of the atmospheric circulation associated with the LIA. Although these results thus point to a similar link as hypothesized here, the $\mathrm{Na}^{+}$peak only lasted for four years. However, if the analogue to present day conditions is valid, it is also possible that the duration of periods with increased westerlies (c. three to four decades; Alexandersson et al., 1998; Siegismund and Schrum, 2001; Furevik and Nilsen, 2005) is longer at lower latitudes than in Greenland.

An alternative and possibly more plausible explanation is based on the assumption that climatic shifts are not causally related to ASI peaks. Decadal scale atmospheric circulation changes in north-west Europe could be related to the extent of sea ice in the Greenland Sea (e.g. Dawson et al., 2002; Smith et al., 2003). Oceanic processes are also related to sea ice extent, and possibly act as a slow mechanism affecting atmospheric circulation on longer time scales. As a consequence of extensive sea ice cover in the Greenland Sea, a southward shift of the Polar front occurs, since high air pressures develop over an ice covered sea. This southward shift of the Polar Front would lead to strongly increased temperature and pressure gradients over the North Atlantic, causing a southward shift of the cyclone track (Dawson et al., 2002) and increased snowfall over Scandinavia (Smith et al., 2003).

A modelling study of cyclones during the Maunder Minimum (MM, AD 1640-1715) shows that fewer cyclones occurred in northern Europe during this time period, but the intensity of the extreme cyclones increased (Raible et al., 2006). These authors suggest that the temperature gradient was higher, particularly in the North Atlantic region where sea-ice extended further south. Increased cyclone intensity may thus be the cause of the reconstructed ASI peak values during the MM. The extent of the sea ice in the Greenland Sea and the associated position of the Polar Front appear to have been important factors determining winter storminess at our study site during the second phase of the Little Ice Age. Unfortunately there are no records on the extent of sea ice covering the entire time period from $1700 \mathrm{cal}$. yrs BP to present, and therefore it is not known whether the mechanism modelled during the ASI peak in the MM can be applied to earlier ASI peaks.

So, we argue that a southward extension of the Polar Front, possibly due to extended sea ice, would result in increased westerly storm intensities on a regional scale, which could have produced the ASI peaks. As an alternative or additional factor, the change in the dominant atmospheric circulation pattern itself - whether or not accompanied by increased sea ice - may have caused increased storminess. The causes for the climatic shifts are, however, unknown. On a longer time scale, $6500 \mathrm{yrs}$, ASI peaks in our study area appear to coincide with periods of low solar irradiance (De Jong et al, 2006). However, many ASI peaks and climatic shifts do not coincide with reduced solar irradiance and therefore solar forcing can not be the only or the main cause for the patterns reconstructed here. An alternative explanation may be that internal climatic oscillations, possibly related to oceanic processes, are the real cause for the climatic changes we record here. A study by Renssen et al. (2006) shows that shifts in oceanic circulation modes are more likely to occur during periods of reduced solar irradiance, but take place also in the absence of solar forcing. This would explain why not all solar irradiance lows are recorded as a climatic change. Our data seem to suggest a two-mode system, with major shifts occurring every $300-400$ years, sometimes coinciding with reduced solar irradiance, but also during periods with normal solar forcing. 


\section{Conclusions}

The direct comparison between testate amoebae inferred bog surface wetness changes and ASI has provided detailed information about the link between two important climatic variables; effective humidity and storminess. The patterns reconstructed from the Undarsmosse bog site are in good agreement with studies from the Store Mosse bog, Vejers dunefield and Lake Igelsjön, indicating that the patterns reflect regional scale changes. Climatic anomalies associated with the e.g. the LIA and MWP are reflected in the Undarsmosse bog as periods with predominantly dry or wet conditions. These are associated with a dominance of continental and oceanic air-masses, respectively. The LIA appears to be divided into two main phases; an early phase dominated by zonal flow and oceanic conditions from ca. 770 to $380 \mathrm{cal}$. yrs BP (AD 1180-1570), and a later phase dominated by meridional flow and more frequent atmospheric blocking from ca. 300 to 50 cal. yrs BP (AD 1650-1900). Shifts in the dominant circulation mode were inferred from relatively rapid changes of the bog surface hydrology, shown by an almost complete transition of the testate amoebae species composition.

The climatic causes of the ASI peaks are as of yet not well understood, but indicate strong atmospheric contrasts. We hypothesize that peak events may be related to the position of the Polar Front and sea ice expansion in the Greenland Sea. Furthermore, a causal link between ASI peaks and the hydrological shifts recorded at Undarsmosse bog is suggested. Solar forcing may have been an indirect forcing factor during some of the peak events, but not all. Human land use changes are thought to not be causally related to ASI peaks, although intense landuse most likely contributed to the high amplitude and long duration of ASI peaks after ca. $350 \mathrm{cal}$. yrs BP.

Future research should focus on the potential relation between storm activity and climatic changes. Modern measurement data as well as modelling studies may help to understand the processes causing increased stormy conditions during periods of climatic change. Such studies are planned for the near future. If climatic shifts are indeed causally related to increased storm activity in this region, extremely severe winter storms such as those recorded in south-west Sweden in January 2005 and January 2007 may become more common as climate continues to change.

Acknowledgements. This study is part of R. de Jong's $\mathrm{PhD}$ thesis (Lund University). The comments and suggestions from three reviewers, D. Charman, H. Seppä and J. Birks, were greatly appreciated and helped to improve the manuscript. We also want to thank D. Charman for his help with the application of the testate amoebae transfer function. The interactive comments from I. Unkel as well as discussions with L. Clemmensen (Copenhagen University) and D. Hammarlund (Lund University) were greatly appreciated.

Edited by: H. Goosse

\section{References}

Adern, N. E. (Ed): Harplinge hembygds och fornminnesfrening: Harplinge, en bok om hembygden. 2nd edition, Laholm, 1973.

Alexandersson, H., Schmith, T., Iden, K. and Tuomenvirta, H.: Long-term variations of the storm climate over NW Europe, Glob Atmos Ocean Syst, 6, 97-120, 1998.

Alexandersson, H., Tuomenvirta, H., and Iden, K.: Trends of storms in NW Europe derived from an updated pressure data set, Clim. Res., 14, 71-73, 2000.

Almquist-Jacobson, H.: Lake-level fluctuations at Ljustjärnen, central Sweden and their implications for the Holocene climate of Scandinavia, Paleogeogr Paleoclimatol Paleoecol, 118, 269-290, 1995.

Barber, K. E., Chambers, F. M., and Maddy, D.: Holocene palaeoclimates from peat stratigraphy: macrofossil proxy climate records from three oceanic raised bogs in England and Ireland, Quat. Sci. Rev., 22, 521-539, 2003.

Berglund, B. E.: Human impact and climate changes - synchronous events and a causal link?, Quat. Int., 105, 7-12, 2003

Berglund, B. E. and Ralska-Jasiewiczowa, M.: Pollen analysis and pollen diagrams, in: Handbook of Holocene palaeoecology and palaeohydrology, edited by: Berglund, B. E., Wiley and Sons, 1986.

Björck, S. and Clemmensen, L. B.: Aeolian sediment in raised bog deposits, Halland, SW Sweden: a new proxy record for winter storminess variation in southern Scandinavia?, Holocene, 14, 677-688, 2004.

Bobrov, A. A., Charman, D. J., and Warner, B. G.: Ecology of testate amoebae from oligotrophic peatlands: Specific features of polytypic and polymorphic species, Biology Bulletin, 29, 605617, 1999.

Bond, G., Kromer, B., Beer, J., Muscheler, R., Evans, M. N., Showers, W., Hoffmann. S., Lotti-Bond, R., Hajdas, I., and Bonani, G.: Persistent solar influence on North Atlantic climate during the Holocene, Science, 294, 2130-2135, 2001.

Borgmark, A.: Holocene climate variability and periodicities in south-central Sweden, as interpreted from peat humification analysis, Holocene, 15, 387-395, 2005.

Borgmark, A. and Schoning, K.: A comparative study of peat proxies from two eastern central Swedish bogs and their relation to meteorological data, J. Quat. Sci., 21, 109-114, 2006.

Bradley, R. S., Briffa, K. R., Cole, J., Hughes, M. K., and Osborn, T. J.: The climate of the last Millennium, in: Paleoclimate, global change and the future, edited by: Alverson, K., Springer, 2002.

Briffa, K. R., Jones, P. D., Schweingruber, F. H., and Osborn, T. J.: Influence of volcanic eruptions on Northern Hemisphere summer temperature over the past 600 years, Nature, 393, 450-455, 1998.

Briffa, K. R., Jones, P. D., Bartholin, T. S., Eckstein, D., Schweingruber, F. H., Karlen, W., Zetterberg, P., and Eronen, M.: Fennoscandian summers from AD 500: temperature changes on short and long timescales, Clim. Dyn., 7, 111-119, 1992.

Bronk Ramsey, C.: Radiocarbon calibration and analysis of stratigraphy: the OxCal program, Radiocarbon, 37, 425-430, 1995.

Bronk Ramsey, C.: Development of the radiocarbon calibration program, Radiocarbon ,43, 355-363, 2001.

Charman, D. J. and Blundell, A.: Accrotelm members: A new European testate amoebae transfer function for palaeohydrological reconstruction on ombrotrophic peatlands. J. Quat. Sci, 2007.

Charman, D. J., Blundell, A., Chiverell, R. C., Hendon, D., and 
Langdon, P.G.: Compilation of non-annually resolved Holocene proxy climate records: stacked Holocene peatland palaeo-water table reconstructions from northern Britain, Quat. Sci. Rev., 25, 336-350, 2006.

Charman, D. J., Brown, A. D., Hendon, D., and Karofeld, E.: Testing the relationship between Holocene peatland palaeoclimate reconstructions and instrumental data at two European sites, Quat. Sci. Rev., 23, 137-143, 2004.

Charman, D. J., Hendon, D., and Woodland, W. A.: The identification of testate amoebae (Protozoa: Rhizopoda) in peats, $Q R A$ Technical Guide No. 9, Quaternary Research Association, London. 147 pp, 2000.

Clarke, M. L., Rendell, H., Tastet, J. P., Clave, B., and Masse, L.: Late-Holocene sand invasion and North Atlantic storminess along the Aquitaine coast, south-west France, Holocene, 12, 231-238, 2002.

Clarke, M. L. and Rendell, H. M.: Effects of storminess, sand supply and the North Atlantic Oscillation on sand invasion and coastal dune accretion in western Portugal, Holocene, 16, 341$355,2006$.

Clemmensen, L. B., Pye, K., Murray, A., and Heinemeier, J.: Sedimentology, stratigraphy and landscape evolution of a Holocene coastal dune system, Lodbjerg, NW Jutland, Denmark, Sedimentology, 48, 3-27, 2001a.

Clemmensen, L. B., Murray, A. S., Bech, J.-J., and Clausen, A.: Large-scale aeolian sand movement on the west coast of Jutland, Denmark in late Subboreal to early Subatlantic time - a record of climate change or cultural impact?, GFF, 123, 193-220, $2001 \mathrm{~b}$.

Clemmensen, L. B., Pedersen, K., Murray, A., and Heinemeier, J.: A 7000-year record of coastal evolution, Vejers, SW Jutland. B Geol Soc Denmark, 53, 1-22, 2006.

Clemmensen, L. B. and Murray, A.: The termination of the last major phase of aeolian sand movement, coastal dunefields, Denmark. Earth surf. Process. Landforms 31, 795-808, 2006.

Crowley, T. J.: Causes of climate change over the past 1000 years, Science, 289, 270-277, 2000.

Dawson, A. G., Hickey, K., Holt, T., Elliott, L., Dawson, S., Foster, I. D. L., Wadhams, P., Jonsdottir, I., Wilkinson, J., McKenna, J., Davis, N. R., and Smith, D. E.: Complex North Atlantic Oscillation (NAO) index signal of historic North Atlantic storm-track changes, Holocene, 12, 363-369, 2002.

Dawson, A. G., Elliott, L., Mayewski, P., Lockett, P., Noone, S., Hickey, K., Holt, T., Wadhams, P., and Foster, I.: Late-Holocene North Atlantic climate 'seesaws', storminess changes and Greenland ice sheet (GISP2) palaeoclimates, Holocene, 13, 381-392, 2003.

De Jong, R., Björck, S., Björkman, L., and Clemmensen, L. B.: Storminess variation during the last 6500 years as reconstructed from an ombrotrophic peat bog in Halland, southwest Sweden, J. Quat. Sci., 21, 905-919, 2006.

De Jong, R.: Stormy records from peat bogs in south-west Sweden -implications for regional climatic variability and and vegetation changes during the past 6500 years, LUNDQUA thesis 58, 2007.

Dijkmans, J. W. A.: Niveo-aeolian sedimentation and resulting sedimentary structures; Sondre Stromfjord area, western Greenland. Permafrost Periglacial process, 83-96, 1990.

Digerfeldt, G.: Reconstruction and regional correlation of Holocene lake-level fluctuations in lake Bysjön, south Sweden, Boreas, 17, 165-182, 1988.
Furevik, T. and Nilsen, J. E.Ø.: Large-scale atmospheric circulation variability and its impact on the nordic seas ocean climate - a review, in: The Nordic Seas: an integrated perspective, edited by: Drange, H., Dokken, T., Furevik, T., Gerder, R., and Berger, W., Geophysical monograph, series 158. American Geophysical union, Washington DC, 105-136, 2005.

Granlund, E.: De Svenska högmossarnas geologi. Deras bildningsbetingelser, utvecklingshistoria och utbredning jämte sambandet mellan högmossebildning och försumpning. Sveriges Geologiska Undersökning, C, 373, 1932.

Grospietsch, Th.: Wechseltierchen (Rhizopodon). Einführung in die Kleinlebewelt. Kosmos. Stuttgart, 1958.

Grove, J. M.: The initiation of the "Little Ice Age" in regions round the North Atlantic, Clim. Change, 48, 53-82, 2001

Gouirand, I., Moberg, A., and Zorita, E.: Climate variability in Scandinavia for the past millennium simulated by an atmosphere-ocean general circulation model, Tellus, 59A, 3049, 2007.

Grudd, H., Briffa, K. R., Karlen, W., Bartholin, T. S., Jones, P. D., and Kromer, B.: A 7400-year tree ring chronology in northern Swedish Lapland: natural climatic variability expressed on annual to millennial timescales, Holocene, 12, 657-665, 2002.

Hammarlund, D., Björck, S., Buchardt, B., Israelson, C., and Thomsen, C. T.: Rapid hydrological changes during the Holocene revealed by stable isotope records of lacustrine carbonates from lake Igelsjön, southern Sweden, Quat. Sci. Rev., 22, 353-370, 2003.

Harplinge hembygd och fornminnesförening: Harplinge -en bok om hembygden. Halmstad, 1927.

Hughes, P. D. M., Mauquoy, D., Barber, K. E., and Langdon, P. G.: Mire-development pathways and palaeoclimatic records from a full Holocene peat archive at Walton Moss, Cumbria, England, Holocene, 10, 467-479, 2000.

Hurrell, J. W.: Decadal Trends in the North-Atlantic Oscillation - Regional Temperatures and Precipitation, Science, 269, 676679, 1995.

Jiang, H., Eiriksson, J., Schulz, M., Knudsen, M.-L., and Seidenkrantz, M.-S.: Evidence of solar forcing of sea-surface temperature on the North Icelandic shelf during the late Holocene, Geology, 33, 73-76, 2005.

Jones, P. D. and Briffa, K. R.: The "Little Ice Age": local and global perspectives, Clim. Change, 48, 5-8, 2001.

Jönsson, P. and Bärring, L.: Zonal index variations, 1899-1992: links to air temperature in southern Scandinavia. Geogr Ann Ser A-Phys Geogr, 76, 207-219, 1994.

Jönsson, P. and Fortuniak, K.: Interdecadal variations of surface wind direction in Lund, southern Sweden, 1741-1990. Intern. J. Clim., 15, 447-461, 1995.

Lamb, H. H.: Climate, history and the modern world, Routledge, London, 1982.

Lewkowicz, A. G.: Aeolian sediment transport during winter, Black Top Creek, Fosheim Peninsula, Ellesmere Island, Canadian Arctic, Permafrost Periglacial Process, 9, 35-46, 1998.

Li, X. Y., Liu, L. Y., and Wang, J. H.: Wind tunnel simulation of aeolian sandy soil erodibility under human disturbance, Geomorphology, 59, 3-11, 2004.

Maasch, K. A., Mayewski, P. A., Rohling, E. J., Stager, J. C., Karlen, W., Meeker, L. D., and Meyerson, E. A.: A 2000-year context for modern climate change, Geogr Ann Ser. A-Phys. Ge- 
ogr, 87, 7-15, 2005.

Matthews, J. A. and Briffa, K. R.: The "Little Ice Age: re-evaluation of an evolving concept, Geogr. Ann. Ser. A-Phys. Geogr., 87, $17-$ 36, 2005.

Mauquoy, D., Engelkes, T., Groot, M. H. M., Markesteijn, F., Oudejans, M. G., van der Plicht, J., and Van Geel, B.: High-resolution records of the late-Holocene climate change and carbon accumulation in two north-west European ombrotrophic peat bogs, Paleogeogr Paleoclimatol Paleoecol, 186, 275-310, 2002.

Mauquoy, D., Van Geel, B., Blaauw, M., and Van der Plicht, J.: Evidence from northwest European bogs shows "Little Ice Age" climatic changes driven by variations in solar activity, Holocene, 12, 1-6, 2002.

Moberg, A., Sonechkin, D. M., Holmgren, K., Datsenko, N. M., and Karlen, W.: Highly variable Northern Hemisphere temperatures reconstructed from low - and high-resolution proxy data, Nature, 433, 613-617, 2005.

Moore, P. D., Webb, J. A., and Collinson, M. E.; Pollen analysis. Blackwell Scientific Publications, 1991.

Nilsson, C., Stjernquist, I., Bärring, L., Schlyter, P., Jönsson, A. M., and Samuelsson, H.: Recorded storm damage in Swedish forests 1901-2000, For. Ecol. Manage., 199, 165-173, 2004.

Ogilvie, A. E. J. and Jonsson, T.: "Little Ice Age" research: a perspective from Iceland, Clim. Change, 48, 9-52, 2001.

Påsse, T.: Jordartskartan Varberg SO/Ullared SV, Serie Ae 86, 1: 50.000 (Quaternary map of Varberg SO/Ullared SV) OffsetCenter AB, Uppsala, 1987.

Påsse, T., Beskrivning till jordartskartan Varberg SO/Ullared SV (Description to the Quaternary map of Varberg SO/Ullared SV), Uppsala, 1988.

Påsse, T.: Jordartsgeologiska kartblad Varberg NO, 1: 50.000, Sveriges Geologiska Undersökning seria Ae 102, Uppsala.

Raab, B. and Vedin, H.: Sveriges Nationalatlas. Bokförlaget Bra Böcker, Höganäs, 1995.

Raible, C. C., Yoshimori, M., Stocker, T. F., and Casty, C.: Extreme midlatitude cyclones and their implications for precipitation and wind speed extremes in simulations of the Maunder Minimum versus present day conditions, Clim. Dyn., 28, 409-423, 2007.

Reimer, P., Baillie, M., Bard, E., Bayliss, A., Beck, J., Bertrand, C., Blackwell, P., Buck, C., Burr, G., Cutler, K., Damon, P., Edwards, R., Fairbanks, R., Friedrich, M., Guilderson, T., Hogg, A., Hughen, K., Kromer, B., McCormac, G., Manning, S., Ramsey, C. B., Reimer, R., Remmele, S., Southon, J., Stuiver, M., Talamo, S., Taylor, F., Van der Plicht, J., and Weyhenmeyer, C.: IntCal04 Terrestrial Radiocarbon Age Calibration, 0-26 cal Kyr BP, Radiocarbon, 46, 1029-1058, 2004.
Renssen, H., Goosse, H., and Muscheler, R.: Coupled climate model simulation of Holocene cooling events; oceanic feedback amplifies solar forcing, Clim. Past, 2, 79-90, 2006, http://www.clim-past.net/2/79/2006/.

Ruddiman, W. F.: Plows, plagues and petroleum - how humans took control of climate, Princeton University Press, New Jersey, 2005.

Schoning, K., Charman, D. J., and Wastegård, S.: Reconstructed water tables from two ombrotrophic mires in eastern central Sweden compared with instrumental meteorological data, Holocene, 15, 111-118, 2005.

Seppä, H., Hammarlund, D., and Antonsson, K.: Low-frequency and high-frequency changes in temperature and effective humidity during the Holocene in south-central Sweden: implications for atmospheric and oceanic forcings of climate, Clim. Dyn., 25, 285-297, 2005.

Shindell, D. T., Schmidt, G. A., Mann, M. E., Rind, D., and Waple, A.: Solar Forcing of Regional Climate Change During the Maunder Minimum, Science, 294, 2149-2152, 2001.

Siegismund, F. and Schrum, C.: Decadal changes in the wind forcing over the North Sea, Clim. Res., 18, 39-45, 2001.

Smith, M., Miller, G. H., Otto-Bliesner, B., and Shin, S.-I.: Sensitivity of the Northern Hemisphere climate system to extreme changes in Holocene Arctic sea ice, Quat. Sci. Rev., 22, 645658, 2003.

Tipping, R.: Holocene evolution of a lowland Scottish landscape: Part 1, peat and pollen-stratigraphic evidence for raised moss development and climatic change, Holocene, 5, 69-81, 1995.

Tsoar, H. and Pye, K.: Dust Transport and the Question of Desert Loess Formation, Sedimentology, 34, 139-153, 1987.

van Geel, B., Buurman, J., and Waterbolk, H. T.: Archaeological and palaeoecological indications of an abrupt climate change in The Netherlands, and evidence for climatic teleconnections around 2650 BP, J. Quat. Sci., 11, 451-460, 1996.

Wilson, P., Orford, J. D., Knight, J., Braley, S. M., and Wintle, A. G.: Late-Holocene (post-4000 years BP) coastal dune development in Northumberland, northeast England, Holocene, 11, 215229, 2001.

Wilson, P., McGourty, J., and Bateman, M. D.: Mid-to late Holocene coastal dune event stratigraphy for the north coast of Northern Ireland, Holocene, 14, 406-416, 2004. 